\title{
THE HEALTH STATUS AND NATURAL REGENERATION OF PINUS SYLVESTRIS L. AFTER THE SURFACE FIRE IN VACCINIOSA FOREST TYPE IN LATVIA
}

Olga MIEZ̄̄TE, Forest Faculty, Latvia University of Agriculture, Latvia, Jelgava, Akademijas Street 11, LV-3001, olga.miezite@1lu.lv (corresponding author)

Jeḷena RŪBA, Forest Faculty, Latvia University of Agriculture, Latvia, Jelgava, Akademijas Street 11, LV-3001, jelena.ruba@1lu.lv Lāsma FREIMANE, Forest Faculty, Latvia University of Agriculture, Latvia, Jelgava, Akademijas Street 11, LV-3001, lasma_freimane@inbox.lv

Imants LIEPA, Forest Faculty, Latvia University of Agriculture, Latvia, Jelgava, Akademijas Street 11, LV-3001, imants.liepa@1lu.lv Edgars DUBROVSKIS, Forest Faculty, Latvia University of Agriculture, Latvia, Jelgava, Akademijas Street 11, LV-3001, edgars.dubrovskis@1lu.lv

From abiotic factors the most effecting influence on forest ecosystems has fire. Two years after surface fire in the pine stands growing in Vacciniosa forest type. Two PL (hereinafter PL) were installed in medium-aged (49 years old, 2.3 ha) and two PLs - in maturing (96 years old, 2.5 ha) stands. In each PL $(20 \times 20 \mathrm{~m})$, the numbering of the trees was carried out and their placement was fixed, as well as the diameter, height and height of the green crown were measured. The sanitary condition of each tree was evaluated. For registration of one-year and two-year seedlings in each sample plot 25 sampling units $\left(1 \mathrm{~m}^{2}\right)$ were used. The similar sampling units were used for evaluation of ground cover (5 in each PL diagonally arranged), the obtained samples were weighed. The purpose of the study was to analyze the health status and natural regeneration of P.sylvestris after the surface fire. The ground vegetation was completely burned out in the medium-aged stand, but in the maturing stand both ground vegetation and organic layer - mosaically. The average burning height of trees in the medium-aged forest stand was $0.6 \pm 0.64 \mathrm{~m}$, in the maturing stand - at $2.3 \pm 0.34 \mathrm{~m}$. The natural regeneration was not detected in the first year after surface fire in the medium-aged forest (only 58800 one-year seedlings were recorded at the second year after fire), while in the maturing stand it was at this time (46600 one-year and 14200 two-year seedlings). Insect damage and cracked bark was not detected.

Keywords: burning height, ground cover, medium age stand, vegetation

\section{INTRODUCTION}

Forest fire is one of the dominant disturbing factors in the boreal forests (Weir et al., 2000). Scots pine Pinus sylvestris $\mathrm{L}$. is one of three the most important tree species in Latvia. The statistics of forest fires in Latvia during the past twenty years have shown that extreme fire has been observed several times. It is expected that in the next 100 years the Latvian air temperature in spring and summer will increase, so should pay more attention to forest fires and analyze their impact on forest stands. The impact of forest fires is one of the topical issues in which the impact of fire on ecosystems, soil and ash properties is studied (Pereira et al., 2012). Since 1990 Latvia has an average of 850 forest fires every year. The highest number of forest fires occurred in 2006, when there were 1925 fires and a burnt area was 3370 ha. In 2002 , 1,742 forest fires broke out and burned 2,364 ha, in 1998 - 356 forest fires and 211 ha, while in 1992 - 1510 forest fires and 8412 ha (Miezīte et al., 2013). In Latvia 641 forest fires with average burnt area of forest stands 0.73 ha in 2016 were recognized, compared to 2015, the average area has decreased by 0.04 ha (State Forest Service, 2016). Fire is decisive feature in different forest ecosystems, including coniferous forests. Fire can form a forest stand structure and vegetation succession (Weir et al., 2000) strongly affecting the physical, chemical and biological environment (DeBano et al., 1998).

Reforestation after fire have crucial role in various fields, including climate change, forest use and management (Senici et al., 2013). After the fire biological properties of soil are changing due to changes of microorganism species and population dynamic, decreasing or disappearing of invertebrate species and partly due to disappearing of plant roots (Doerr, Cerdà, 2005). Namely the changes of substrates and ecosystems depend on fire intensity level and the type of current vegetation (Adamonytė et al., 2016).

Copyright (C) 2017 The Authors. Published by Aleksandras Stulginskis University. This is an open-access article distributed under the terms of the Creative Commons Attribution License (CC-BY 4.0), which permits unrestricted use, distribution, and reproduction in any medium, provided the original author and source are credited. 
Burnt-out forest areas should be allowed to regenerate naturally, without human intervention (Chen et al., 2014). The aim of current study was to analyze natural regeneration of Scots pine (Pinus sylvestris L.) in medium-aged and maturing stands in Vacciniosa forest site type two years after medium intensity surface fire and to evaluate the sanitary condition of the trees affected by the fire.

\section{RESEARCH METHODS}

The empirical data was collected in two surface fire affected Scots pine stands in forest site type Vacciniosa. First stand - 46 years old middle-aged mixed Scots pine stand (10\% silver birch in stand composition), located in block No. 214 and forest plot No. 3 (henceforth 214/3), coordinates (X57.03244;Y24.36422), stand size class - II, total burnt-out area -2.3 ha. Second one - 96 years old maturing pure stand of Scots pine, located in block No. 213 and forest plot No. 16 (henceforth 213/16), coordinates (X57.03724; Y24.36575), stand size class - III, total burnt-out area - 2.5 ha. In each forest plot two square temporary sample plots (henceforth SP) were installed, 20x20 m. SP were divided into quadrants. All Scots pine trees were listed, and diameter at breast height $1.3 \mathrm{~m}$ above root collar for all Scots pine trees in SP was measured with calliper (accuracy $0.1 \mathrm{~cm}$ ). Tree height and crown height for each tree with height meter VERTEX were measured (precision $0.01 \mathrm{~m}$ ). SP for each tree the lowest and highest points of combustion were measured using a measuring tape.

Wooden stencil $(1 \times 1 \mathrm{~m})$ for natural regeneration evaluation was created. It was divided by twining into four equal parts. One-year-old and two-year-old Scots pine seedlings were counted on intersection of quadrants using aforementioned wooden stencil $\left(1 \mathrm{~m}^{2}\right)$ (Figure 1).

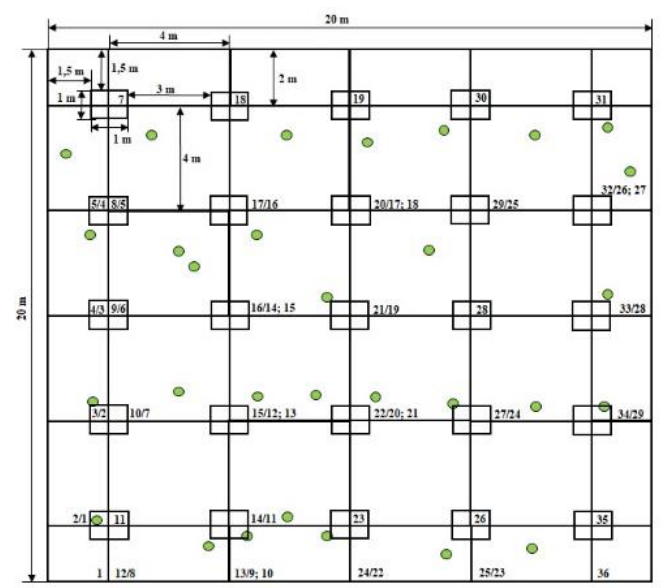

Figure 1. Scheme for forest stand dendrometric measurements and setting up sample plots for counting one-year-old and two-yearold seedlings in Scots pine stands.

Five 1x1 m large sample plots for ground litter collecting and weighing were installed in each SP on the diagonal (accuracy up to $10 \mathrm{~g}$ ). Dendrometric parameters of measured forest stands were calculate using formula $1-7$.

$$
D_{g}=\sqrt{\frac{g_{\text {vid }}}{0.785}} \cdot 100
$$

where $D_{g}$ - the average tree diameter of forest stand, what was calculated from average basal area of a single tree ( $\left.g_{v i d}\right)$, $\mathrm{cm} ; g_{\text {vid }}$ - average basal area of forest stand, $\mathrm{m}^{2}$.

For stem volume calculation were used aligned heights, which were obtained from the regression equation of the altitude curve. For tree height $(y)$ calculation was used logarithmic regression equation (2.2), which has a higher determination coefficient $\left(R^{2}\right)$, which best illustrates the empirical distribution of tree diameter and height parameters:

$$
y=a \operatorname{Ln}(x)-b
$$

where $x$ - tree diameter, $\mathrm{cm} ; a$ - regression coefficient; $b$ - free member of the regression equation.

The following algorithm for stem volume $\left(V, m^{3}\right)$ determination was used (Liepa, 1996):

$$
V=\psi^{*} L^{\alpha} * D^{\beta \lg L+\varphi}
$$

where $L$ - stem length, $\mathrm{m} ; D$ - stem diameter with bark, $\mathrm{cm} ; \psi, \alpha, \beta, \varphi$ - empirically determined coefficients (for Scots pine $\left.-\Psi=1.6541 \cdot 10-^{4}, \alpha=0.5682, \beta=0.25924, \varphi=1.59689\right)$. 


$$
g=0.7854 \cdot \frac{D^{2}}{10000},
$$

where $g$ - basal area of a single tree in the sample plot, $\mathrm{m}^{2}$.

$$
G=\frac{g}{L} \cdot 10000
$$

where $G$ - basal area of the stand according to sample plot data, $\mathrm{m}^{2}$ ha ${ }^{-1} ; L$ - sample plot area, $\mathrm{m}^{2}$.

$$
N=\frac{N p \cdot 10000}{L}
$$

where $N$ - number of tree per hectare according to sample plot data, pcs. ha ${ }^{-1} ; N p$ - number of trees in sample plot, pcs. $\mathrm{ha}^{-1}$.

$$
M=\frac{V p \cdot 10000}{L}
$$

where $M$ - growing stock according to sample plot data, $\mathrm{m}^{3} \mathrm{ha}^{-1}$.

Descriptive statistics with $95 \%$ of credibility for empirical data analysis was used. Analysis of variance (ANOVA) was used to analyze significance difference between gradation classes.

\section{RESEARCH RESULTS}

\section{Dendrometric indicators of Scots pine stand affected by surface fire and sanitary condition in Vacciniosa}

Forests suffer from different natural disasters including forest fire (Bušs, 1989). Origin and spreading probability of forest fire depends from forest ecosystem properties (Jansons, 2010; Pereira et al, 2012). Vacciniosa forest site type with very thin detritus layer developed on poor podzolic soil from sandy mother rock, and target tree species is Scots pine (Bušs, 1989). Dendrometric indicator values (Table 1) of middle age Scots pine stand affected by surface fire with site index III in Vacciniosa are as follows: $\mathrm{D}_{\mathrm{g}}=18.4 \mathrm{~cm}, \mathrm{H}_{\mathrm{g}}=15.8 \mathrm{~m}, \mathrm{~g}=0.0267 \pm 0.00209 \mathrm{~m}^{2}$; average tree volume of the stand $(\mathrm{V})$ is $0.2044 \pm 0.01761 \mathrm{~m}^{3}$ and the average height of the tree crown starts at $5.9 \pm 0.31 \mathrm{~m}$. Stand growing stock $-76 \mathrm{~m}^{3} \mathrm{ha}^{-1}$ but stand basal area $-10.0 \mathrm{~m}^{2} \mathrm{ha}^{-1}$. Dendrometric indicator values in maturing Scots pine stand with site index II in Vacciniosa are as follows: $\mathrm{D}_{\mathrm{g}}=34.0 \pm 0.75 \mathrm{~cm} ; \mathrm{H}_{\mathrm{g}}=24.3 \pm 0.29 \mathrm{~m} ; \mathrm{g}=0.0907 \pm 0.00201 \mathrm{~m}^{2}$; average tree volume of the stand is $0.9783 \pm 0.01761 \mathrm{~m}^{3}$ and the average height of the tree crown starts at $5.9 \pm 0.31 \mathrm{~m}$. Stand growing stock $-325 \mathrm{~m}^{3} \mathrm{ha}^{-1}$, stand basal area $-30.6 \mathrm{~m}^{2} \mathrm{ha}^{-1}$.

Table 1. Dendrometric indicator values of wild fire damaged Scots pine stands in Vacciniosa $(\alpha=0.05)$

\begin{tabular}{|c|c|c|c|c|c|c|c|c|}
\hline Coordinates & $\begin{array}{c}\text { Block/ } \\
\text { plot }\end{array}$ & $\begin{array}{c}\text { Species } \\
\text { composition }\end{array}$ & $\mathrm{D}_{\mathrm{g}}, \mathrm{cm}$ & $\mathrm{H}_{\mathrm{g}, \mathrm{m}}$ & $\begin{array}{c}\mathrm{G}_{\text {vid. }} \\
\mathrm{m}^{2}\end{array}$ & $\mathrm{~V}_{\text {vid., }} \mathrm{m}^{3}$ & $\begin{array}{c}\mathrm{G}, \\
\mathrm{m}^{2} \mathrm{ha}^{-1}\end{array}$ & $\begin{array}{c}\mathrm{M}, \\
\mathrm{m}^{3} \mathrm{ha}^{-1}\end{array}$ \\
\hline $\begin{array}{l}57.03244 \\
24.36422\end{array}$ & $214 / 3$ & $9 \mathrm{P}_{4} \mathrm{~B}_{4}$ & 18.4 & 16.1 & $0.0267 \pm 0.00209$ & $0.2044 \pm 0.01761$ & 10.0 & 76 \\
\hline $\begin{array}{l}57.03724 \\
24.36575\end{array}$ & $213 / 16$ & $10 \mathrm{P}_{96}$ & 34.0 & 24.3 & $0.0907 \pm 0.00201$ & $0.9783 \pm 0.01761$ & 30.6 & 325 \\
\hline
\end{tabular}

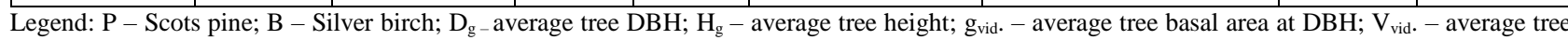
volume; $\mathrm{G}$ - stand basal area; $\mathrm{M}$ - stand growing stock.

After surface fire in middle-age and maturing Scots pine stands was detected that every tree was more or less damaged by fire (Figure 2). Burned average lowest point in middle age Scots pine stand (9P1B 49$)$ was at $0.6 \pm 0.64 \mathrm{~m}(\mathrm{~min}$ $0.2 \mathrm{~m}$, max $1.7 \mathrm{~m})$, burned average highest point was at $3.1 \pm 0.18 \mathrm{~m}(\min 0.6 \mathrm{~m}, \max 3.6 \mathrm{~m})$ but in maturing stand $\left(10 \mathrm{P}_{96}\right)$ accordingly $-2.3 \pm 0.34 \mathrm{~m}(\min 0.3 \mathrm{~m}, \max 2.6 \mathrm{~m})$ and $-4.6 \pm 0.25 \mathrm{~m}(\mathrm{~min}-2.6 \mathrm{~m}$, max- $6.0 \mathrm{~m})$. Highest burns were stated on resin Scots pine trunks despite the fact that in surface fire were damaged practically all trees in both stands and cracked bark was not detected.

One of factors affecting tree mortality is tree diameter (Freimane et al., 2013) thereby higher surface fire persistence

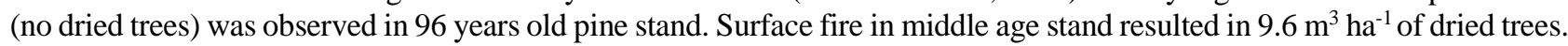
In pine stands trees with thicker bark have greater fire persistence. Tree roots were protected from getting burned due to forest fire broke out in the spring, in April, when the organic layer is not yet fully embroidered and do not chars. 


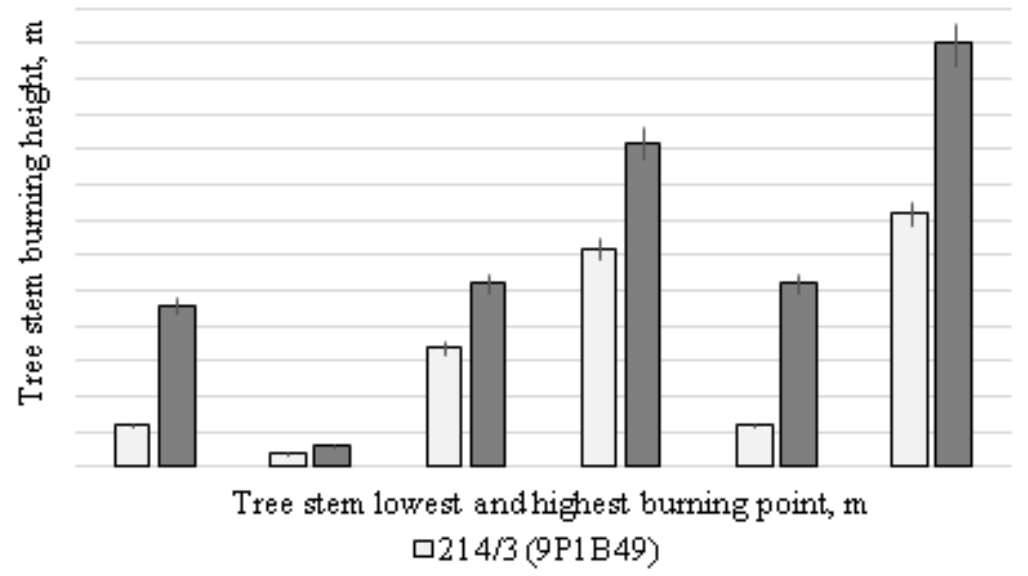

Figure 2. Scots pine tree stem lowest and highest burn height, min and max in middle age (9P1B 49$)$ and maturing (10P 96 ) stand.

Visually inspecting each PL tree stem two years after spring surface fire insect damage was not spotted.

\section{Scots pine stand natural regeneration after surface fire}

Fire causes great forest biocenosis destruction and large loss for national economics. It damages or completely destroys growing trees, shrubs and ground cover. After devastating impact of fire in forest area changes light, moisture and temperature regimes (Miezite et al., 2013). In both research stands thin undergrowth was completely destroyed. Only one species - common juniper (Juniperus communis L.) was completely burned. Also ground cover was burned and ground vegetation was destroyed in both Scots pine stands while in maturing stand $213 / 16\left(10 \mathrm{P}_{96}\right)$ ground vegetation in mosaic texture was burned. Remaining ground cover was gathered, weighted and in data processing was stated that in middle age pine stand $214 / 3\left(9 \mathrm{P}_{1} \mathrm{~B}_{49}\right)$ remaining ground cover weight was $7.5 \pm 0.55 \mathrm{t} \mathrm{ha}^{-1}$ but in maturing stand $213 / 16$ $\left(10 \mathrm{P}_{96}\right)-6.9 \pm 1.36 \mathrm{tha}^{-1}$.

In $P$. sylvestris stands moss layer delays seed sprouting (Steijlen et al., 1995). Forest regeneration in every forest stand starts after the fire (Engelmark et al., 1998; Gromtsev, 2002). Two years after fire was stated that in middle age pine stand $214 / 3\left(9 \mathrm{P}_{1} \mathrm{~B}_{49}\right)$ were only one-year-old seedlings - 58800 3094 per ha but in maturing stand $213 / 16\left(10 \mathrm{P}_{96}\right)-$ $46600 \pm 2452$ per ha one-year-old and $14200 \pm 747$ per ha two-year-old seedlings (Figure 3). Number of seedlings per sample plot confirms fact that one-year-old seedlings were uniform distributed but two-year-old seedlings unequally as they were found only in $1 / 3$ of maturing stands sample plots in soil outcrops.

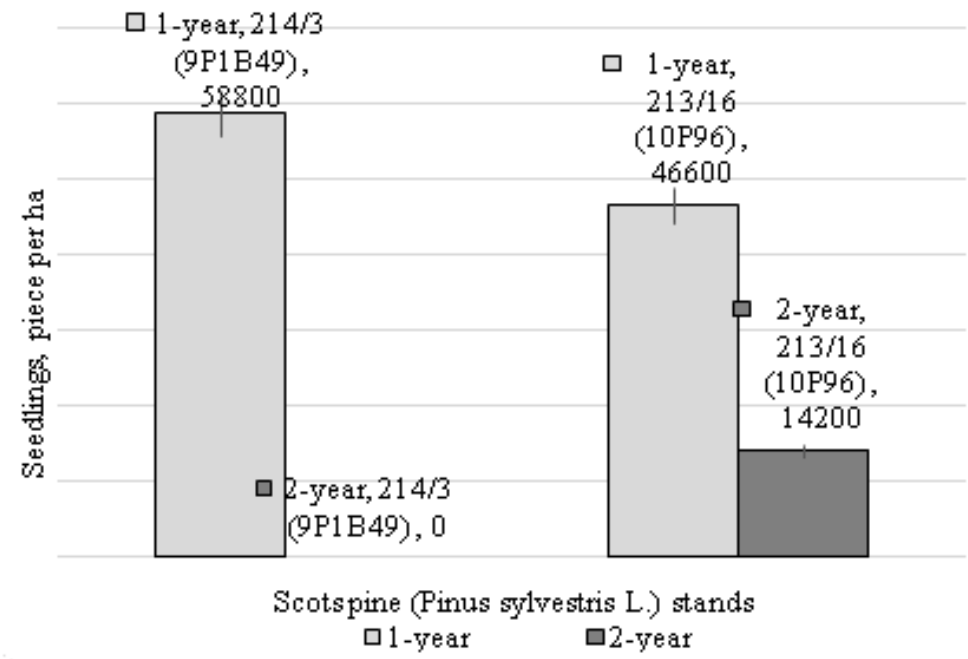

Figure 3. Natural regeneration of Scots pine in middle age 214/3 (9P1B 49$)$ and maturing 213/16 (10P96) stands after 2 years after surface fire in Vacciniosa (average number of seedlings $\pm \mathrm{SE}$ ).

Two-year-old seedlings were found only in the outcrops of 96 -year-old maturing pine stand. Therefore, the placement of two-year-old seedling is very uneven, since $2 / 3$ of the sample plots two-year-old seedlings were not found.

\section{CONCLUSIONS AND DISCUSSION}

Tree stability and health status depends on affected by surface fire stand age, average diameter, ground cover density and time of year. Tree roots are not affected, because a forest fire broke out in the early spring, when ground cover is not yet 
fully embroidered, so it does not contribute smoldering (Liepa, 1991). After fire in 49-age old Scots pine stand (9P1B $\left.{ }_{49}\right)$ the remaining weight of ground cover forms $7.5 \pm 0.55 \mathrm{t} \mathrm{ha}^{-1}$, while in the maturing stand $\left(10 \mathrm{P}_{96}\right)-6.7 \pm 1.36 \mathrm{t}^{-1}$. Adamonyté et al. (2016) concluded that the changes in substrate and ecosystem depend on the degree of fire intensity and type of existing vegetation. The sanitary condition is found to be critical in 49-year-old Scots pine medium-aged stand with site index III $\left(\mathrm{D}_{\mathrm{g}}=18.4 \mathrm{~cm}\right)$ and it's better in 96-year-old Scots pine maturing stand with site index II $\left(\mathrm{D}_{\mathrm{g}}=34.0 \mathrm{~cm}\right)$ in Vacciniosa. Trees that died as a result of surface fire have been detected only in medium-aged stand $\left(9.6 \mathrm{~m}^{3} \mathrm{ha}^{-1}\right)$. Two years after the spring surface fire, damage of pests and cracked bark in the stand were not detected. Two years after forest fire in $P$. sylvestris medium-aged $\left(9 \mathrm{P}_{1} \mathrm{~B}_{49}\right)$ and maturing stand $\left(10 \mathrm{P}_{96}\right)$ was detected successful regeneration. In mediumaged stand were only one-year-old, while in maturing stand - both one-years and two-year-old seedlings. Two-year-old seedlings occur only in the outcrops of the soil. In P. sylvestris stands ground vegetation and ground cover dense layer hinder seed germination Steijlen, Zackrisson (1987). After surface fire in Scots pine stands forest litter forms a relatively dense layer of clay thus disturbing fallen pine seeds to reach the soil and interrupt germination. In general the cumulative effect of fire and drought can lead to a different landscape configurations (Battlori et al., 2017). This explains why twoyear-old pine seedlings were not found in the middle-aged stand as there were not detected outcrops after the surface fire. Due to the fact that only two stands in Scots pine habitats with typical regeneration were studied, it cannot be excluded that results of the research may differ using higher number of repetitions.

\section{REFERENCES}

1. Adamonytė G., Motiejūnaitė J., Iršėnaitė R. 2016. Crown fire and surface fire: effects on myxomycetes inhabiting pine plantations. Science of the Total Environment, Vol. 572, pp. 1431-1439.https://doi.org/10.1016/j.scitotenv.2016.02.160

2. Batllori E., Dećaceres M., Brotons L., Ackerly D., Moritz M., Lloret F. 2017. Cumulative effects of fire and drought in Mediterranean ecosystems. Ecosphere, Vol. 8, Iss. 8, Available at http://onlinelibrary.wiley.com/doi/10.1002/ecs2.1906/abstract;jsessionid=4DFB13B796A69FFFCBD8AC6E17EE2721.f02t04 (Accessed on 03/11/2017).

3. Bušs K. 1989. Forest Ecosystems. Rīga, Zvaigzne. [In Latvian]

4. Chen W., Moriya K., Sakai T., Koyama L., Cao C. 2014. Post-fire forest regeneration under different restoration treatments in the Greater Hinggan Mountain area of China. Ecological Engineering, Vol. 70, pp. 304-311. https://doi.org/10.1016/j.ecoleng.2014.06.016

5. DeBano L., Neary D., Ffolliott P. 1998. Fire's Effects on Ecosystems. Wiley, New York.

6. Doerr S., Cerdà A. 2005. Fire effects on soil system functioning: new insights and future challenges Int. Journal of Wildland Fire 14, pp. 339-342. https://doi.org/10.1071/WF05094

7. Engelmark O., Hofgaard A., Arnborg T. 1998. Successional trends 219 years after fire in an old Pinus sylvestris stand in northern Sweden. Journal of Vegetation Science, Vol. 9, pp. 583-592.https://doi.org/10.2307/3237274

8. Freimane L., Miezīte O., Ailts M., Meiere N., Luguza S. 2013. Response reaction of Scots pine Pinus sylvestris L. after forest fire in forest site type Vacciniosa turf.mel. in Klivve forest district. Rural Development 2013: Innovations and Sustainability, Vol. 3, Book 2, pp. 272-279, Aleksandras Stulginskis university.

9. Gromtsev A. 2002. Natural disturbance dynamics in the boreal forests of European Russia: a review. Silva Fennica, Vol. 36, pp. 41-55.https://doi.org/10.14214/sf.549

10. Jansons A. 2010. Pine forests dying in different forest growth conditions. Research for Rural Development, Vol. 2, 36-43, Latvia University of Agriculture [In Latvian].

11. Liepa I. 1996. Increment Study. Jelgava, Latvia University of Agriculture. [In Latvian]

12. Liepa I., Mauriņš A., Vimba E. 1991. Ecology and nature protection. Rīga, Zvaigzne. [In Latvian]

13. Miezīte O., Indriksons A., Dreimanis A., Freimane L. 2013. The consequences of the forest fire in Sphagnosa forest site type ecosystem. Rural Development 2013: Innovations and Sustainability, Vol. 3, Book 2, pp. 355-359, Aleksandras Stulginskis University.

14. Pereira P., Cepanko V., Vaitkute D., Pundyte N., Pranskevicius M., Zuokaite E., Úbeda X., Mataix-Solera J., Cerdà A. 2012. Grassland fire effects on ash properties and vegetation restoration in Lithuania (North-Eastern Europe). Flamma, Vol. 3, Book 1, pp. 3-8, Mykolas Romeris University, Vilnius, Vilnius Gediminas Technical University, University of Barcelona, Miguel Hernandez University, University of Valencia.

15. Senici D., Lucas A., Chen H., Bergeron Y., Larouche A., Brossier B., Blarquez O., Ali A. 2013. Multi-millennial fire frequency and tree abundance differ between xeric and mesic boreal forests in central Canada. Journal of Ecology. Vol. 101, pp. 356367.https://doi.org/10.1111/1365-2745.12047

16. State Forest $\quad$ Service. 2016. Public review. Available https://www.zm.gov.lv/public/files/CMS_Static_Page_Doc/00/00/01/06/16/Publiskais_parskats_2016.pdf (Accessed on 03/11/2017)

17. Steijlen I., Zackrisson O. 1987. Long-term regeneration dynamics and successional trends in a northern Swedish coniferous forest stand. Canadian Journal of Botany, Vol. 65, pp. 839-848.https://doi.org/10.1139/b87-114

18. Weir J., Johnson E., Miyanishi K. 2000. Fire frequency and the spatial age mosaic of the mixed-wood boreal forest in western Canada. Ecological Applications, 10, pp. 1162-1177. https://doi.org/10.1890/1051-0761(2000)010[1162:FFATSA]2.0.CO;2 